\title{
Acmeologic bases of scientific and pedagogical personnel training in the conditions of masters program
}

Botagul Altayevna Turgunbayeva ${ }^{1}$, Elvyda Martišauskiené ${ }^{2}$, Bakhytzhamal Zhorabekovna Bekzhanova ${ }^{3}$, Valentina Khristofova Kelsievna ${ }^{4}$

1 Kazakh National Pedagogical University Abai,

13 Dostykave, 050010 Almaty, e-mail botagul53@mail.ru

2 Lithuanian University of Educational Sciences, Faculty of Education, Department of Education, Studentų St. 39, LT-08106 Vilnius, Lithuania, e-mail elvyda.martisauskiene@leu.lt

Kazakh National Pedagogical University Abai, 13 Dostykave, 050010 Almaty, e-mail bekzhanova77@ mail.ru Institute of increasing educators' qualification in the Almaty region

Annotation. Acmeology is considered as a science that studies the achievements of high level professionalism of the individual. The essence of teaching Acmeology is disclosed. Methodological approaches to the study of acmeologic training of Masters are identified. Acmeologic factors that contribute to the professional competence formation of Master's program students are studied.

Keywords: pedagogical acmeology, acmeologic approach, professional competence, professional development, acmeologic factors.

\section{Introduction}

The Republic of Kazakhstan has entered a new quality of life of the community that requires market content of human capital. Changes in the system of social relationships affect the education and require an adequate response to the realities of the new historical stage. This defines the search for and implementation of new approaches to professional training, the content of which would be directed primarily to the personality formation, ready to act effectively in an ever-changing social-economic conditions; to the personality that is creative, professionally mobile, and capable of continuing professional self-development and self-improvement. 
Three-staged higher education in Kazakhstan (Bachelors Program, Master's Program - PhD Program) at a postgraduate stage assume specialized of Masters and PhDs training capable to do research of psychological and pedagogical problems of an education system, to pedagogical and scientific activity in higher educational institutions. The Master of Pedagogy should be prepared to solve the professional and educational tasks corresponding to his degree (qualification) that assumes: pedagogical science methodology acquisition and independent research and pedagogical activity skills demanding broad education in the corresponding direction; possession of the ability to formulate and solve the problems arising during professional activity, to process the received results, to analyze and comprehend them taking into account available data etc.

According to the European Qualifications Framework for Higher Education ('Dublin descriptors') a graduate student is characterized as that is able to demonstrate a deep current knowledge in the specialized field/discipline: knowledge of the latest theories and their interpretations, methods and techniques, to evaluate critically and interpret the latest achievements of the theory and practice, to own the methods of conducting independent research and interpretation of its results, to make their own original contribution to the field (thesis), to demonstrate originality and creativity in activities relating to a particular area.

Obviously such requirements for professionals brings acmeology. In Russian-speaking context there are many studies that analyze the problem of acmeologic approach in various areas: professionalism achievement (A. A. Bodalev (1998), A. K. Markov (1996), A. Derkach (2004), humanitarian-technological development of public employees (A. S. Gussev, A. A. Derkach (1997) of teacher's activity (N. V. Kuzmina (1990), of effective military labor (L. Laptev (1998), of training (A.P.Sitnikov, 1996), of adaptive school teachers (L. V. Antropov, 2004), of new quality of education (V. Maksimov (2004), of the teachers competence development (O. A. Kozyrev (2006), etc. But there is no study as acmeologic basis can contribute to the scientific and pedagogical personnel training in the conditions of Masters Program.

We believe that the implementation of acmeologic aspect in the current system of postgraduate education will encourage creativity, revealing fruitful use of personal resources to succeed in the profession of the future teacher.

The foregoing results in a high degree of urgency of the problem of creating acmeologic oriented system of future teachers training and dictates the choice of the theme of our research "Acmeological Aspects of The Scientific and Pedagogical Personnel Training at the Stage of Post-Graduate Education."

The research objective consists in the theoretical and methodological substantiation of acmeologic training of scientific and pedagogical personnel.

The research object is the essence of acmeologic approach.

The research tasks:

- To disclose acmeology as a science that studies the personality to achieve a high level of professionalism; 
- To discover the essence of pedagogical acmeology;

- To identify methodological approaches to the study of acmeologic training of masters;

- To reveal acmeologic factors contributing to the formation of undergraduates professional competence.

The research methods: systematic, the selection of materials for the research problem, the analytical analysis of the scientific literature, conclusion formulation.

\section{Acmeology as a Science of Professional Development}

Acmeologic ideas of personality development were expressed by many philosophers of the antiquity. For example, the basic acmeologic concept about self-realization of personality creative potential is closely related to the concept "self-movement" in the meaningful relation that was introduced by Plato. And the concept "Acmeology" (from Greek acme - top, peak, dawn) was introduced by N. A. Rybnikov in 1928 for the first time, for designation of the special section of Age Psychology - Maturity and Adulthood Psychology (Акмеологические проблемы подготовки преподавателей, 1998, p. 6; Деркач, Зазыкин, 2003, p. 28). This term appeared in rough intellectual and social search of the 20th when such scientific branches as Eurilogy (P. Engelmeyer (1971), Ergonology (V. N. Myasishchev (1995), Reflexology (V. M. Bekhterev) (Психология. Словарь, 1990) appeared.

In the middle of XX century - B. G. Ananyev determined the place of Acmeology in the system of sciences on a man, and in the 90's (A. A. Bodalev and A. Derkach) the first Department of Acmeology and Psychology of Professional Activity was created in the Russian Academy of Public Service under the President of the Russian Federation. After two years in St. Petersburg (N. Kuzmina, A. Derkach), scientific and social organization "Academy of Acmeologic Sciences" was created. In 1995 St. Petersburg Acmeologic Academy, now - St. Petersburg Institute of Psychology and Acmeology was established.

Due to the Specialty Passport of Higher Attestation Commission, acmeology, as an integrative science, refers to both the pedagogical and psychological fields of science and expresses the modern view of human development.

The object of Acmeology is a developing personality at the level of maturity. The subject in a broad sense - both objective and subjective factors that contribute to or hinder the progressive development of a mature personality, the conditions under which an adult can reach the highest level of productivity in his professional activity, creativity, relationships and development. These are "factors and conditions of self-realization of the creative human potential on the way to higher achievements in life and activity, both professional and non-professional” (Кузьмина-Гаршина, Лунева, 1995, p. 3).

The Greeks used the word "acme" to describe the period of age in human life, when a maturity of all, what a given person is able to do when he is unfolded, blossomed at the top of their abilities" (Кузьмина, 2001, p. 11). According to A. A. Derkach (2004), acme 
is a multidimensional condition of a person, even though it includes significant extent of his life, but it always really shows, as far as the person took place as the citizen, as the professional - personality.

Acmeology as a new science is defined in different ways. Some authors (N. V. Kuzmina, G. I. Choziaynov and others) mostly refer to the dissemination of a person's creative power and maintain that "acmeology is the science about the regularities, conditions, factors and incentives that promote or hinder the self-realization of creative potentials of mature people in the process of self-movement to the heights of professionalism and productivity of creative activity, embodied in the socially significant product of culture, art, literature, science, technology, education as well as in man" (Кузьмина, 2001, p. 12), or that "acmeology is an integrative science that studies the laws, ways and means, the conditions of human creativity peaks achievement and the ways of his self-realization in creative activities during maturity" (Хозяинов, 1991, p. 5), or that "acmeology is a new area of scientific knowledge in the system of sciences about man, exploring the fundamental laws of creation and self-creation of productive professional in a man" (Кузьмина, 2001, p. 184), etc.

Other scientists (A. A. Bodaliov, J. A. Gagin) focus on the development of a human being as a personality, indicating that "acmeology is the science that studies phenomenology, the laws and implementation mechanisms of the human capacity as species, individual, person, subject of the activity (including collective, group), the individual when he reaches the highest level, the height of his development at various stages" (Гагин, 2000, p. 26); "acmeology is the science that occurred at the intersection of natural, social, humanity and technical disciplines and studying phenomenology, patterns and mechanisms of human development at the stage of maturity, and, especially, at their achievement of the highest level in this development" (Бодаев, 1998, p. 5).

It is obvious that the merging of both trends presupposes a fundamental approach to acmeology as a science, which, according to B. G. Ananyev, is directed to a systematic study of man as an individual, the person, the subject of activity, personality, its self-realization in the actions and products of creativity.

It is understandable that "acmeology as science has its own system of concepts, which do not exist in other sciences. As V. N. Tarasova points out, such basic concepts include: maturity, professional activity, top craftsmanship, and professionalism" (Тарасова, 1997, p. 17).

Based on the analysis of acmeology genesis, scientific research (Пожарский, 2002) and personal practice, the following methodological principles can be distinguished:

- principle of vertices (acmeology investigates the laws of the top achievement in all kinds of self-employment);

- the principle of holism (acmeology synthesizes itself knowledge from various scientific fields);

- the principle of historicism (acmeology reveals acmeologicness at various stages of history); 
- multilateralism (acmeology examines human tops achievement in different areas of activity, and this is the acme of his);

- the principle of development (acmeology studies the process of aman self-development as the self-realization of his creativity potential);

- the principle of integrity (acmeology serves as an integrative science).

It is noteworthy that the level of professional maturity of the person and so-called top of this maturity (acme) is a multifunctional condition of the person which does not appear unexpectedly at once. All previous life of the individual "works" for it including deeply scientifically and checked on efficiency professional education. As a result it will define what kind of knowledge graduate of professional school will have in a level of his active maturity, what valuable orientations and relations are the core of the person, and what kind of knowledge, skills and abilities reserve will characterize him as the subject-creator and the subject-professional.

High professionalism and creative skills of the experts are one of the major human resources that become a factor of the optimal solution of urgent global and crisis problems. In this social-cultural context a new science of acmeology has special value. It studies regularities and techniques of professionalism and creativity development as acme-forms of optimal implementation of any possible types of professional activity.

As above mentioned S. D. Pozharsky (2002) suggested at this stage of acmeology it is possible to say about the following classification of this science:

- Classical acmeology (considering a person in terms of his mentality development at period of his maturity)

- Fundamental (basic) acmeology (considering man as a complete system)

- Applied (sectoral) acmeology (consideration of a man through the prism of specific problems of special knowledge).

Scientists distinguishes four basic stages in the development of acmeology (Деркач, 2004, p. 93):

- Latent - imperceptible and gradual folding of the historical, cultural, social, philosophical, scientific, educational, practical background in scientific knowledge allocation of acmeologic scope of human studies;

- Nominate - awareness of social needs in such knowledge;

- Incubatory - the emergence of the conceptual idea of the need to design studies of acmeologic issues and promotion of deployment program of acmeology as a separate discipline;

- Institutional - the creation of social structures: acmeologic departments and faculties, laboratories at universities and the International Academy of Acmeologic Sciences.

In terms of methodology, acmeology is the science of complex fundamental and applied nature. Fundamentality is determined by cognition of the sphere of reality, not studied by other sciences. Applied character of acmeology appears in practically oriented acmeological techniques. 
Basic categories of acmeology at this stage of its development are: professionalism, skill, competence, creativity, creative work, creative potential, professional, and vocational development.

\section{The Essence of Pedagogical Acmeology}

The history of acmeology shows that Pedagogy has a special place in the development of acmeology, as "the real design of acmeology as disciplinary area began with the dawn of Pedagogical Acmeology. <....> on the first stage of acmeology, its object was primarily professionalism of teachers activity" (Педагогическая акмеология, 2012, p. 18). But soon it became clear that the problems of the professional, personal, subjective and individual becoming of a human being embrace not only the work of the teacher. Research was begun and new forms of acmeology were being formed, the concept of pedagogical acmeology was being developed as well.

The most common definition is based on the fact that pedagogical acmeology is the science of how to achieve the professionalism and competence of teachers. But this does not satisfy the definition of many researchers. The fact that "subject matter, object and subject of pedagogical acmeology are broader than the science of how to achieve the professionalism of teachers" (Педагогическая акмеология, 2012, p. 24). In other words, in the pedagogical work students, the subjects of pedagogical impact that fix themselves their behavior and activities are involved. Not only that, during the mutual influence it is necessary to take into account not only the physical, mental, and spiritual features of the personality that help to realize that it is necessary to develop. Only the "positive trend in the development of man as an individual, subject and individuality should be the key indicator of pedagogical acmeology" (Педагогическая акмеология, 2012, p. 35). As pedagogical acmeology is defined as the science "of the laws and ways of the maximum possible disclosure of their human potentialities, and on this basis to achieve optimal results in a progressive positive development as a person, subject, individual, and individuality - as an integrated multi-dimensional person - in a specially organized educational process" (Педагогическая акмеология, 2012, p. 36). In other words, according to V. N. Maximova (2004), acmeology is the science of human qualities and the quality of life; and acmeologic approach to education is particularly relevant in connection with the growing problem of the quality of modern school. Hence the fundamental categories of pedagogical acmeology take new aspects, the origins of that lie in the educational process that is based on subject-subject interaction.

From analyzing data of the definition of "pedagogical acmeology", own approach is being defined: pedagogical acmeology studies man as a spiritual being, personality and subject of activity, the individual, his / her individual characteristics as a whole and as an integrated multi-dimensional person with spiritual, intellectual and physical potential; considers the laws and ways of disclosing this potential on the basis of the achieved results, which combine the development of the educator and learner. 
Professionalism is the widest on the content acmeology category. The more difficult is to determine the professionalism of the teacher. Under this term it is understood the integral characteristics of business and personal qualities of specialists reflecting the level of knowledge, skills, experience sufficient to produce a certain kind of activity which is related to decision-making. Professionally competent teacher is seized the professional knowledge and skills, the ability to not only design his activities, but also to manage the pedagogical process responsive to any changes in the educational process specialist. According to N. V. Kuzmina (1990), the professionalism of the teacher activity is that the teacher knows the art to form the students willingness to productive problem solving; can develop a personality of the students with the help of his subject aids; is ready to use all of his internal resources (genuine pedagogical orientation, pedagogical skills, and self-learning etc.) for the development of the personality of students and their preparation for successful entry into the following educational systems. Generally speaking overall professionalism of the teacher is in the fact that he knows how to teach and educate students; how to transfer them from one state of proficiency, accomplishment, education to another, and doing this in a fast and economic way.

A very complex phenomenon is also pedagogical creative work. We could not find unequivocal definition of this concept essence in scientific works. S. L. Rubinstein characterizes creativity as "the activity of the person creating new material and cultural values that have public importance" (Рубинштейн, 1986, p. 14).

By V. I. Andreev's (1988) definition, defining creativity as a human activity, it has a number of indications characterizing it as complete process:

- contradiction existence of the problem situation or creative task;

- social and personal importance and progressiveness that makes a contribution to the society and personality development (antisocial activity, even in its inventive form it is not creativity, it is barbarity);

- objective (social, material) preconditions existence, conditions for creativity;

- subjective preconditions existence for creativity (personal qualities - knowledge, abilities, especially positive motivation, creative abilities of the personality);

- novelty and originality of the process or result.

Creativity is creative possibilities (abilities) of the person that can be shown in thoughts, feelings, communication, separate kinds of activity characterizing the personality as a whole and/or its separate parties, activity products, process of their creation. "Creativity (P. Torrens) is the process of sensuality appearance to the problems, to the defect or disharmony of available knowledge, these problems definition, search of their solutions, hypotheses promotion, checking, changing and rechecking of hypotheses, and at last, formation and the decision result announcement" (Torrance, 1974, p. 14).

In addition, the development of creativity promotes the formation of creative maturity of the specialist in the process of personality self-actualization and the achievement of his personal, professional and spiritual peaks (acme). With the high level of self-actualization 
of the creative person creative maturity of the specialist is more sustainable, productive and long life in reality is a creative source of artistic maturity (Вишнякова, 1996).

The creative potential is defined as the intellectual and creative precondition for creativity (D. B. Bogoyavlenskaya (1983), as the gift available for each person, as integrated dynamic personal education (A. I. Savenkov (2010), as patrimonial property of the person, as the ability for new production (A. I. Sannikova (2001). From A. M. Matyushkina's (1991), point of view the creative potential represents the integrative personal quality expressing person's concern to creativity. Y. A. Ponomarev (1976), V. I. Andreev (1994), E. V. Bondarevskaya (1999), A. V. Khutorskoy (2003) recognize that the creative potential development is promoted by personality activity that is presented as intellectual, subject and other types of the activity. And in the opinion of S. D. Pozharsky (2002), a global acme (top self-organization) both the individual and society, is to turn all of humanity into the spiritual community of creative people.

What is the novelty of teacher creativity? V. A. Kan-Kalik and N. D. Nikandrov (1990) consider pedagogical creativity as "the most difficult transformation of the person by the person". Other researchers see in creativity the most expressed freedom of human spirit's display that is difficult or impossible to analyze scientifically (Кан-Калик, Никандров, 1990, p. 56).

Professional competence (from Latin "competens" - "corresponding", "capable", "possessing competence", "expert") of the teacher is considered as the high level of readiness due to strategy knowledge of the productive pedagogical activity, interrelating its structural components and criteria for measurement of its efficiency degree.

Professional competence is an important component and indicator of high level of professionalism. Professional competence is manifested in the successful resolution of a certain class of professional tasks, which is the basis of different types of competence (social, perceptual, communicative, and organizational, etc.) (Акмеологический словарь, 2004, p. 47-48).

When we use the concept "professional competences", we accept that "professional competences" are obtaining of the productive techniques complex of the professional activity based on the possession of professionally important personal qualities providing abilities of the personality to implementation of his productive professional activity and aspiration to professional self-improvement. Professional competence is the generalization of psychological and acmeologic category.

The Master degree studies assume the formation of different types of undergraduates' competences: persona, social, socio-psychological, communicative, conceptual and professional. Educational process of Masters Program is connected with competence problems - the block of questions that future master should solve functionally and be responsible for their decisions. Competence as ability for knowledge integration, abilities and ways of their application in the conditions of changing requirements of the external sphere includes: set of similar knowledge, abilities and relations necessary for successful work performance. 
Professional development is the process of the appearance of high-quality progressive change of mentality and personality work in his mastering the profession and fulfilment of professional activity, which is closely related to the personal formation of the subject of work, and advancing, and blocking it (Акмеологический словарь, 2004, p. 105-106).

Professional development is a process in which man is able to maintain the quality and the level of his professional skills throughout his life. In other words it is not enough to become a professional pro once. In order to remain professional, it is needed continuous professional development of the individual, which should not be a duty or a mere formality, but a way of thinking, a healthy habit. From the point of view of the public interest, the professional development of the individual can be seen as one of the items of code of professional ethics: a person, who is not working on himself, cannot be considered as a professional, as the main feature of professional activity is the reliance on scientific knowledge.

Acmeology investigates the ways to optimize professional development; designs the ways to stimulate a man as the subject of his professional self-development; enhances the techniques of his the most complete self-realization, professional vertices achievement (Акмеологический словарь, 2004, p. 105-106).

\section{Methodological Approaches to the Study of Acmeologic Training of Masters}

Analysis of the scientific literature, own practice shows that at the study of acmeologic training of the scientific and pedagogical personnel in the conditions of Masters Program it is appropriate to be based on the following methodological approaches:

- System approach that considers all the components of pedagogical system in close relationship with each other (goals, objectives, content, principles, forms and methods of teaching undergraduates) (E. G. Yudin (1978); V. V. Kraevsky (2008);

- Subject approach: a core factor of acmeologic system is the personality of the future specialist, which is the subject of immediate self-improvement and improvement vicarious with own activities and acmeologic techniques (B. G. Ananyev (1968), S. L. Rubinstein (1986), N. V. Kuzmina (2001), A. A. Derkach (2003) and others);

- Competence-based approach, involving the formation of the future specialist's competence and is the base from the point of view of determining the quality of specialist training in the educational environment of the Masters Program (I. A. Zimnyaya (2003), A. V. Khutorskoy (2003) etc.);

- Activity approach, asserting the activities as the basis, means, and the main subject of development and personality formation, oriented on the personality for the organization of creative work as the most effective transformation of the world; allowing to determine the most optimal conditions for the development of the individual in the process of activity (S. L. Rubinstein (1986), A. Leontyev (1997), etc.); 
- Cultural approach, considering human relation to the culture as a system of values, and is a development of the person, his formation as a creative person and the subject of culture (N. D. Nikandrov (1990); V. L. Slastenin (1991), E. V. Bondarevskaya (1999), etc.).

For integrating with respect to the rest of the methodological approaches actually stands acmeologic approach oriented towards the formation of future professional affirmation for the highest achievements; the most complete self-realization in the learning process at the stage of post-graduate education (B. G. Ananyev (1968), A. A. Bodalev (1998), N. V. Kuzmina (2001), A. O. Derkach (2004).

Acmeologic approach is an implementation of the "comprehensive investigation and restoration of the integrity of the subject passing the period of maturity when his individual, personal and subject-activity characteristics are studied in unity, in all the relationships and mediations, in order to facilitate the achievement of his higher levels, at which everyone can go uр" (Акмеологические проблемы подготовки преподавателей, 1998, р. 51).

Acmeologic approach is the generalizing key term, acting as a body of principles, methods and techniques allowing to solve acmeologic problems.

\section{Acmeologic Factors Contributing to the Formation of Undergraduates Professional Competence}

In the result of research of scientific literature and own practice acmeologic factors contributing to the formation of undergraduates professional competence are established (Акмеологический словарь, 2004, р. 161):

Objective factors: system maintenance of specialists training quality; a professional orientation of the organisation of independent creative work; the use of innovative techniques; creation of the conditions providing Master degree students professional competence formation.

Subjective-objective factors: the teamwork organisation; relations in educational group and work staff; the Masters Program students group activity organisation promoting social activity motives development and ability to work in a team.

Subjective factors: creative abilities; flexibility and efficiency of thinking; professional abilities system and development; professional-significant qualities system development (an ingenuity, organizational abilities, teamwork, consciousness, responsibility, goodwill, loyalty, tolerance, etc.); an innovative orientation and exposure to experience, inquisitiveness; broad-mindedness; ability to form a team; orientation to quality and result; an orientation of the person towards business and dialogue; the expressed motivation of achievement, informative and social motives; aspiration to professional knowledge, abilities, which lead to expanding the output of creativity within the background of the perfection of personal qualities. 


\section{Conclusions}

Research of acmeologic problems of professional education is relevant, requiring the identification, validation of the theoretical apparatus of acmeology of professional education, improvement of the professional competence of the specialists of professional education, taking into account the integrative character of pedagogy.

The new paradigm having arisen at the intersection of social, technical, humanity and natural sciences acmeology solves the problems of identification of optimal factors and conditions that allow an adult to mature as an individual, personality and subject of activity that is to reach his "acme" (especially in professional activities). The development of acmeology is caused by the necessity of studying the holistic image of the person, including the process of the formation and patterns of human development at the stage of adulthood, considering his personal history in earlier age stages.

Pedagogical acmeology has been defined as the science of the laws and the ways of the maximum possible disclosure of human own potentials, and on this basis, optimal results in a progressive positive development as a person, subject, individual and personality as an integrated multi-dimensional human being in a specially organized educational process have been achieved. It is important to improve the quality of education and it offers the prospect of a new model of future teachers' training and it is aimed at solving the problem of human capital development.

\section{Literature}

Акмеологические проблемы подготовки преподавателей. (1998). Под редакцией Н. В. Кузьминой,

Е. С. Гуртовой. Москва: Шуя.

Акмеологический словарь. (2004). Под общ. ред. А. А. Деркача. Москва: Изд-во РАГС.

Ананьев, Б. Г. (1968). Человек как предмет познания. Ленинград: ЛГУб.

Андреев, В. И. (1994). Эвристика для творческого саморазвития. Казань: КГУ.

Антропова, Л. В. (2004). Как использовать акмеологические технологии учителю адаптивной школы. Воспитание школьников, № 3.

Большой психологический словарь. (2004). Сост. Б. Мещеряков, В. Зинченко. Олма-пресс. Богоявленская, Д. Б. (1983). Интеллектуальная активность как проблема творчества.

Ростов: Издательство Ростовского университета.

Бодалев, А. А. (1998). Вериина в развитии взрослого человека. Характеристики и условия достижения. Москва: Флинта; Наука.

Бондаревская, Е. В. (1999). Педагогика: личность в гуманистических теориях и системах воспитания. Учебное пособие. Ростов на Дону: Изд-во РОИУУ.

Вишнякова, Х. Ф. (1996). Кретивная акмеология. Докторская диссертация. Москва. 
Гагин, Ю. А. (2000). Концептуальньй словарь-справочникпо педагогической акмеологии. Учебное пособие. Санкт-Петербург: СПбГУПМ, Балт. пед. Академия.

Гусева, А. С., Деркач, А. А. (1997). Оптимизация гуманитарно-технологического развития государственных служащих: теория, методология, практика. Москва: Агентство «КВАНТ».

Деркач, А. А., Зазыкин, В. (2003). Акмеология. Учебное пособие. Санкт-Петербург: Питер.

Деркач, А. А. (2004). Акмеологические основы развития профессионализма. МоскваВоронеж.

Зимняя, И. И. (2003). Ключевые компетенции-новая парадигма результата образования. Высшее образование сегодня, № 5, с. 15-19.

Кан-Калик, В. А., Никандров, Н. Д. (1990). Педагогчческое творчество. Москва: Педагогика.

Козырева, О. А. (2006). В поиске акмеологических оснований развития компетентности учителя. Начальная школа плюс до и после, № 2, с. 15-18.

Кузьмина, Н. В. (1990). Профессионализм личности преподавателя и мастера производственного обучения. Москва: Высш. шк.

Кузьмина, Н. В. (2001). Акмеологическая теория повышения качества подготовки специалистов образования. Москва: Исследовательский центр проблем качества подготовки специалистов.

Кузьмина, Н. В. (2000). Акмеология. Методические и методологические проблемы. Под редакцией Н. В. Кузьминой, А. М. Зимичева. Санкт-Петербург: СпбАА.

Кузьмина-Гаршина, Н. В., Лунева, Л. Ф. (1995). Проблемы воспитания учащейся молодежи: Российская конферениия с международным участием: Тезисы докладов и сообщений. Под ред. Н. А. Лобанова. Санкт-Петербург: Черкесск: Изд. Акме-Петербург.

Краевский, В. В., Бережнова, Е. В. (2008). Методология педагогики. Москва: Академия.

Лаптев, Л. Г. (1998). Акмеологические основы эффективного воинского труда: монография. Москва: ИТАР-ТАСС.

Леонтьев, А. Н. (1997). Деятельность. Сознание. Личность. Москва: Наука,.

Максимова, В. Н. (2004). Акмеология: новое качество образования. Завуч., № 3, 6, 7, 8.

Маркова, А. К. (1996). Психология профессионализма. Москва: Знание.

Матюшкин, А. М. (1991). Развитие творческой активности. Москва: Знание.

Мясищев, В. Н. (1995). Психология отношений. Под редакцией А. А. Бодалева. Москва: Издательство «Институт практической психологии», Воронеж: НПО<МОД ЭК>.

Пожарский, С. Д. (2002). Синергетическая акмеология. Докторская диссертация. СанктПетербург.

Пономарев, Я. А. (1976). Психология творчества и педагогика. Москва: Педагогика,.

Психология. Словарь. (1990). Под. обш. ред. А. В. Петровского, М. Г. Ярошевского. 2-е изд., испр. и доп. Москва: Политиздат.

Педагогическая акмеология: коллективная монография. (2012). Под. ред. О. Б. Акимовой, ФГАОЫ БПО <<Рос.гос. проф.-пед. ун-т>>, Екатеринбург.

Рубинштейн, С. Л. (1986). Основы общей психологии. Москва: Педагогика. 
Савенков, А. И. (2010). Психология детской одаренности. Москва: Генезис.

Санникова, А. И. (2001). Формирование готовности учащихся к развитию своего творческого потенциала в образовательном процессе. Учебное пособие. Перм. гос. пед. ун-т.

Ситников, А. П. (1996). Акмеологический тренинг: Теория. Методика. Психотехнологии. Москва: Технологическая школа бизнеса.

Сластенин, В. Л. (1991). Педагогика творчества. Советская педагогика, № 1, с. 147-149.

Тарасова, В. Н. (1997). Акмеология. Научная сессия. Под редакцией Н. В. КузьминойГаршиной, А. М. Зимичева. Санкт-Петербург: СпбАА.

Torrance, E. P. (1974). Tests of Creative Thinking. Scholastic Testing Service, Inc.

Хозяинов, Г. И. (1991). Греческо-русский словарь. Москва: ГЛК Ю. А. Шичалина.

Хуторской, А. В. (2003). Дидактическая эвристика: Теория и технология креативного обучения. Москва: Изд-во МГУ.

Энгельмейер, П. К. (1971). Теория творчества. Санкт-Петербург: «ЛКИ».

Юдин, Э. Г. (1978). Системный подход и принцип деятельности: методологические проблемы современной науки. Москва: Наука.

\section{Mokslinių-pedagoginių kadrų rengimo magistrantūroje akmeologiniai aspektai}

Botagul Altayevna Turgunbayeva ${ }^{1}$, Elvyda Martišauskiené ${ }^{2}$, Bakhytzhamal Zhorabekovna Bekzhanova ${ }^{3}$, Valentina Khristofova Kelsievna ${ }^{4}$

1 Kazachstano Abajaus nacionalinis pedagoginis universitetas,

Dostyk pr. 13, Almata, el. paštas botagul53@ mail.ru

2 Lietuvos edukologijos universitetas, Ugdymo mokslų fakultetas, Edukologijos katedra, Studentų g. 39, LT-08106 Vilnius, el.paštas elvyda.martisauskiene@leu.lt

KazachstanoAbajaus nacionalinis pedagoginis universitetas,

Dostyk pr. 13, Almata, el. paštas bekzhanova77@ mail.ru

4 Almatos Mokytojų kvalifikacijos kèlimo institutas (Kazachstano Respublika)

\section{Santrauka}

Straipsnyje analizuojamos būsimų pedagogų rengimo sistemos, orientuotos ị akmeologiją, kūrimo metodologinès problemos.

Nuosekliai pristatoma rusiškai kalbančiose šalyse išplètoto akmeologijos mokslo, Rusijos VAK pase priskiriamo integruotam mokslui, implikuojančiam pedagogikos ir psichologijos mokslų šakas ir išreiškiančiam šiuolaikinị požiūrị ị žmogaus raidą, svarba rengiant magistrus, nes akmeologija nukreipta ị suaugusio žmogaus (dažniausiai 25-40 metų) laikotarpi, siekiant asmenybės ir profesinès veiklos aukštumų (gr. akme - viršūnè, sužydejjimas). 
Teoriniu-metodologiniu lygiu grindžiami mokslinių-pedagoginių kadrų rengimo magistrantūroje akmeologiniai pagrindai: pateikiama akmeologinių problemų tyrimo švietimo sistemoje analizé; išryškinti akmeologijos metodologiniai principai, pamatinès kategorijos; pristatyti akmeologiniai veiksniai (objektyvūs, subjektyvūs-objektyvūs, subjektyvūs), darantys poveikị magistrantų profesinės kompetencijos formavimuisi, apibrèžta pedagoginė akmeologija kaip mokslas, kuris tiria žmogų kaip asmenybę, veiklos subjektą, individą, individualybę, jo individualias ypatybes, apskritai kaip vientisą, daugiamatị žmogų su intelektiniu ir moraliniu potencialu, atskleidžia dėsningumus ir kelius šio potencialo sklaidai jų pasiektų rezultatų tyrimo pagrindu. Todèl akmeologiniai aspektai svarbūs planuojant ir organizuojant magistrantūros studijas, o ypatingą svarbą igyja rengiant mokslinius-pedagoginius kadrus, kurių profesionalumą didele dalimi lemia asmenybiniai veiksniai.

Esminiai žodžiai: akmeologija, pedagogine akmeologija, akmeologinè prieiga, profesinè raida, profesinis kompetentingumas.

Iteikta / Received 2013-05-01

Priimta / Accepted 2014-01-29 